\title{
PENILAIAN KESEHATAN BANK SYARIAH
}

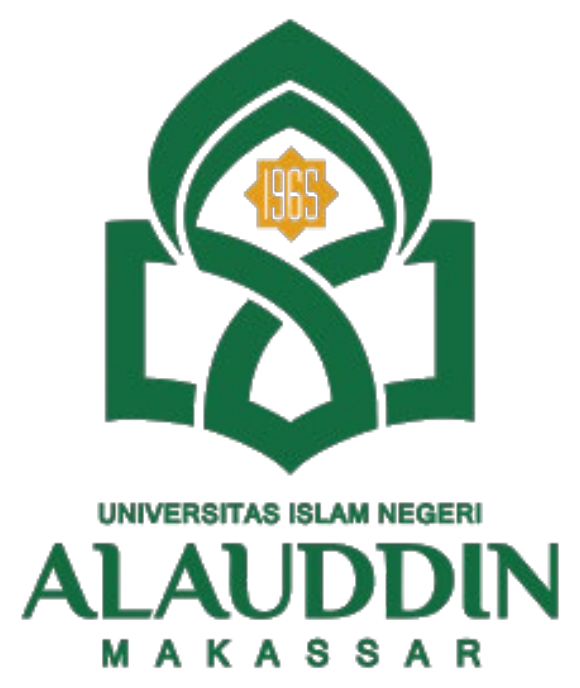

\author{
MAKALAH \\ Disusun untuk memenuhi tugas makalah mata kuliah Audit Perbankan \\ Syariah semester 5 Tahun 2021
}

Oleh :

Novira Putri Arlianti (90500119072)

Dosen:

St. Hafsah Umar, M.Ak

PERBANKAN SYARIAH

FAKULTAS EKONOMI DAN BISNIS ISLAM

UIN ALAUDDIN MAKASSAR

2021/2022 


\section{KATA PENGANTAR}

Puji syukur Alhamdulillah, saya selaku penyusun panjatkan kehadirat Allah SWT. yang telah melimpahkan segala rahmat, taufik dan hidayah-Nya sehingga makalah ini yang berjudul "Penilaian Kesehatan Bank Syariah" dapat terselesaikan.

Tak lupa pula shalawat serta salam semoga tercurah limpahkan pada junjungan kita Nabi Muhammad SAW. yang telah membawa kita dari zaman yang penuh kegelapan menuju zaman yang terang - menderang.

Melalui makalah ini saya berharap pembaca dapat memahami dan mengetahui lebih banyak tentang materi ini. Saya menyadari bahwa masih banyak kesalahan dan kekurangan di dalam penulisan makalah ini. Segala bentuk saran dan kritik dari para pembaca yang dapat bermanfaat bagi perbaikan dan perkembangan makalah selanjutnya.

Makassar, November 2021

Penyusun 


\section{DAFTAR ISI}

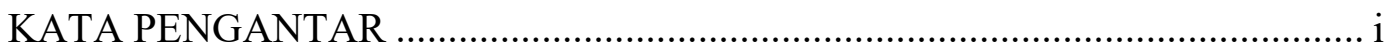

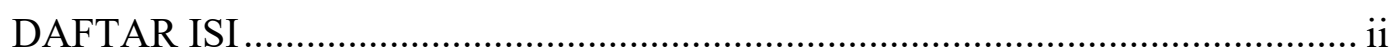

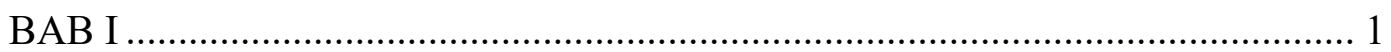

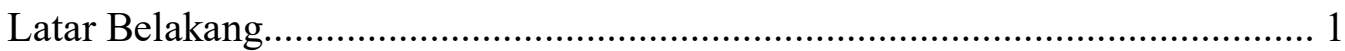

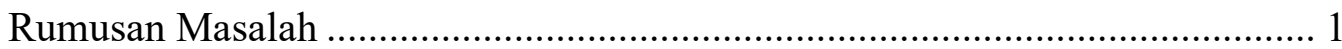

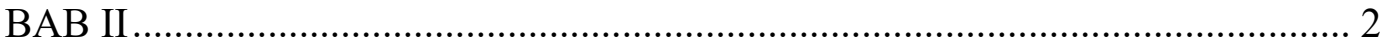

A. Konsep Penilaian Kesehatan Bank............................................................... 2

B. Pemenuhan Peraturan Perbankan ............................................................... 2

C. Analisis Capital Adequacy Ratio (CAR) ………………………………... 10

D. Financing To Deposit Ratio (FDR) .......................................................... 11

E. Non-Performance Financing (NPF) …………………………………….. 12

F. Beban Operasional Terhadap Pendapatan Operasional (BOPO) ................ 12

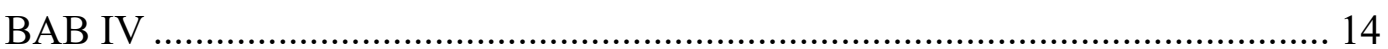

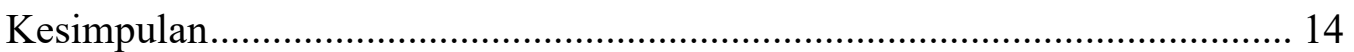

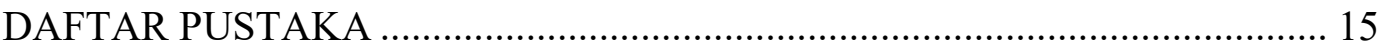




\section{BAB I}

\section{PENDAHULUAN}

\section{Latar Belakang}

Begitu pesatnya perkembangan industri perbankan Indonesia yang ditandai dengan banyaknya bank-bank yang sedang berkembang, maka pengawasan terhadap bank-bank tersebut sangat diperlukan. Dalam hal ini, Bank Indonesia sebagai bank sentral perlu melakukan pengawasan terhadap bank untuk memahami status keuangan dan kegiatan usaha masing-masing bank. Oleh karena itu, Bank Indonesia melaporkan neraca dan rekening administratif, daftar rincian surat berharga yang dimiliki dan diterbitkan, daftar rincian pinjaman yang diberikan, daftar rincian investasi, daftar rincian laba rugi, dan daftar lainnya yang wajib dilaporkan secara berkala. kepada Bank Indonesia.

\section{Rumusan Masalah}

1. Bagaimana Konsep Penilaian Kesehatan Bank

2. Bagaimana Pemenuhan Peraturan Perbankan

3. Bagaimana Analisa Capital Adequacy Ratio (CAR)

4. Bagaimana Financing To Deposit Ratio (FDR)

5. Bagaimana Non-Performance Financing (NPF)

6. Bagaimana Beban Operasional Terhadap Pendapatan Operasional (BOPO) 


\section{BAB II}

\section{PEMBAHASAN}

\section{A. Konsep Penilaian Kesehatan Bank}

Tingkat penilaian kesehatan bank merupakan hasil penilaian kondisi bank dalam rangka mengatasi risiko dan kinerja bank, dapat juga dikatakan penilaian kesehatan bank merupakan cerminan dari kinerja fungsi bank. Bank yang sehat adalah bank yang dapat menjaga dan memelihara kepercayaan masyarakat, dapat berperan sebagai intermediasi, dapat membantu kelancaran arus pembayaran, dan dapat digunakan oleh pemerintah untuk melaksanakan berbagai kebijakan khususnya kebijakan moneter.

Kasmir (2008:41), mengatakan bahwa kesehatan bank dapat diartikan sebagai kemampuan bank untuk menyelenggarakan kegiatan operasional perbankan secara normal dan melaksanakan semua kewajibannya dengan baik sesuai dengan ketentuan perbankan yang berlaku.

Berdasarkan Surat Keputusan No. 30/12/KEP/DIR tanggal 30 April 1997, dan Surat Edaran No. 30/3/UPPB tanggal 30 April 1997 tentang Tata Cara Penilaian Tingkat Kesehatan Bank disebutkan bahwa Tingkat Kesehatan Bank Tingkat kinerja pada dasarnya dievaluasi melalui analisis kualitatif terhadap berbagai faktor yang mempengaruhi status dan perkembangan bank. ${ }^{1}$

\section{B. Pemenuhan Peraturan Perbankan}

\section{a. Rasio Kewajiban Penyediaan Modal (RKPMM)}

\footnotetext{
${ }^{1}$ Ireyne Filania Raturandang and others, 'Surat Edaran Bank Indonesia No:6/23/DPNP Tanggal 31 Mei 2004', Journal of Chemical Information and Modeling, 53.9 (2013), 1689-99.
} 
Rasio Kecukupan Modal Minimum (KPMM) merupakan rasio kecukupan modal bank atau kemampuan bank untuk menutupi kerugian kredit atau transaksi surat berharga dalam modal yang ada. Rasio modal digunakan untuk mengukur kemampuan bank untuk menyerap yang tidak dapat dihindari. Kerugian, juga dapat digunakan untuk mengukur kekayaan bank atau kekayaan pemegang sahamnya.

\section{b. Penetapan Batas Maksimum Pemberian Kredit (PBMK)}

Persentase terbesar dari realisasi dana yang diberikan kepada permodalan BPR, termasuk kredit dan penempatan dana BPR pada bank lain, tidak termasuk giro atau disebut BPMK. BMPK Untuk pihak berelasi, seluruh portofolio dana bank yang diberikan kepada pihak berelasi ditetapkan paling banyak 10\% (sepuluh persen) dari modal bank.

Yang dimaksud dengan pihak yang terkait dengan bank adalah debitur dan/atau kelompok debitur yang mempunyai hubungan kekerabatan dengan bank.

1. $10 \%$ pemegang saham individu

2. $10 \%$ atau lebih pemegang saham dalam bentuk badan/perusahaan

3. Anggota Komite

4. Anggota keluarga terkait. Hubungan keluarga di atas tingkat kedua, baik secara horizontal maupun vertikal, mengacu pada pihak-pihak berikut:

a) orang tua kandung/orang tua tiri/orang tua angkat;

b) Saudara/Langkah/Adopsi;

c) biologis/ayah tiri/anak angkat;

d) Kelahiran/ayah tiri/kakek atau kakek-nenek angkat;

e) Kelahiran/ayah tiri/cucu angkat;

f) Saudara laki-laki dan perempuan dari orang tua/ayah tiri/angkat; dll.

5. Mengarah kepada satu peminjam yang bukan ialah pihak terpaut pastikan sangat besar $20 \%$ dari modal bank.

6. Pejabat Bank. Maksudnya merupakan pejabat yang memiliki tugas eksekutif, ialah pengaruh terhadap operasional bank serta/ ataupun 
bertangguung jawab langsung kepada direksitermasuk pejabat satuan keja audit internal serta dewan audit.

7. Penyediaan Dana kepada sekelompok Peminjam yang bukan ialah Pihak Terpaut diresmikan sangat besar 25 dari Modal Bank.

8. Peminjaman dalam satu kelompok kedapatan melanggar BMPK serta pelanggaran salah satu kelompok Peminjam yang merupakan anggota kelompok Peminjam tersebut, maka perhitungan pelanggaran hanya terhadap kelompok Peminjam, namun action plan penyelesaian pelanggaran hendaknya dilakukan untuk kedua pelanggaran BMPK tersebut. ${ }^{2}$

\section{c. Penentuan Kualitas Aktiva Produktif}

Penerima manfaat kualitas aktiva produktif merupakan salah satu kriteria untuk mengevaluasi hasil bank syariah. Dan untuk menjaga hasil yang baik dalam perbankan syariah, Anda harus selalu berpegang pada prinsip kehati-hatian dan prinsip Syariah. Salah satu kriteria untuk menjaga kualitas aset produksi adalah penerapan kebijakan yang mengalokasikan dana pada sektor ekonomi, sektor industri, dan sektor penjualan. Demikian pula hubungan antara dana dan sumber daya dengan memperhatikan alokasi sumber daya dan alokasi risiko sehingga aset yang dihasilkan benar-benar dapat memberikan kontribusi bagi pendapatan bank

a. Pendanaan adalah penyediaan dana berdasarkan akad Muharabah dan/atau pendanaan lainnya berdasarkan prinsip penagihan dan/atau bagi hasil. Dalam perbankan keuangan tradisional dan kredit, kualitas pembiayaan bank syariah dibagi menjadi 4 kelompok: lancar, tidak standar, dipertanyakan dan tidak menguntungkan.

b. Piutang atau tagihan transaksi proses penjual belian barang atau sewa menyewa barang menggunakan akad mudharabah, salam, istishna, dan

\footnotetext{
${ }^{2}$ Ramlan Ginting and Dkk, Kodifikasi Peraturan Bank Indonesia ASET, 2013.
} 
ijarah. Piutang lancar, kurang lancar, dalam perhatian khusus, diragukan dan macet merupakan penggolongan piutang.

c. Surat yang biasanya diperdagangkan pada pasar modal ataupun pasar uang dengan berdasarkan prinsip syariah disebut bukti surat berharga Syariah atau surat bukti berinvestasi.

d. Penanaman pada BPRS atau dana syariah sesuai prinsip syariah berupa wadiah atau giro, deposito, pembiayaan, sertifikat IMA dan tabungan mudharabah atau bentuk penempatan lainnya disebut penempatan.

e. Penanaman dana pada perusahaan yang dalam pengoperasiannya dibidang syariah berbentuk sura utang dengan saham atau jenis transaksi lain berdasarkan prinsip syariah dan akan mempunyai saham didalam perusahaan bergerak dibidang keuangan syariah merupakan penanaman dana oleh bank syariaah dalam bentuk saham atau disebut penyertaan modal.

f. Kewajiban berdasarkan prinsip syariah dalam bentuk bank garansi, penjaminan emisi, letter of credit (L/C) yang tidak dapat dibatalkan dan jaminan berbasis syariah lainnya merupakan transaksi rekening administratif.

Kualitas aset penerima dievaluasi berdasarkan tingkat pemulihan. Klasifikasi pemulihan aset produksi saat ini terbatas hanya pada kredit yang diberikan. Tindakan utama untuk menentukan jumlah pokok dan bunga, kemampuan sipeminjam dalam hal bisnis dan nilai jaminan pinjaman terkait. Menurut kualitas penerima manfaat aset dapat dibagi menjadi lima, yaitu:

a) Lancar (Pass), jika memenuhi kriteria:

1. Pembayaran angsuran pokok dan/atau bunga tepat waktu

2. Memiliki mutase rekening yang aktif

3. Bagian dari kredit yang dijamin dengan agunan tunai (Cash Collateral)

b) Dalam perhatian khusu (Special Mention), jika memenuhi kriteria: 
1. Terdapat masalah tunggakan angsuran pokok dan/atau bunga yang belum melampaui 90 hari

2. Kadang-kadang terjadi cerukan

3. Mutase rekening relative aktif

4. Didukung oleh pinjaman baru, dan lain-lain.

c) Kurang lancer (Substandard), jika memenuhi kriteria:

1. Terdapat masalah tunggakan angsuran pokok dan/atau bunga yang telah melampaui 90 hari

2. Sering terjadi cerukan

3. Mutase rekening relative rendah

4. Lemahnya dokumentasi pinjaman

5. Terdapat beberapa masalah keuangan yang dihadapi oleh debitur, dan lainlain.

d) Diragukan (Doubtful), jika memenuhi kriteria:

1. Terdapat masalah tunggakan angsuran pokok dan/atau yang telah melampaui 180 hari

2. Terdapat cerukan yang sifatnya permanen

3. Terjadi wanprestasi lebih dari 180 hari

4. Terjadi kapitulasi bunga, dan lain-lain.

e) Macet (Loss), jika memenuhi kriteria:

1. Terdapat masalah tunggakan angsuran pokok dan/atau bunga yang telah melampaui 270 hari

2. Kerugian operasional yang ditutup dengan pinjaman baru 
3. Dari segi hukum serta kondisi pasarnya, jaminan tidak dapat dicairkan pada batas nilai wajar. ${ }^{3}$

\section{d. Kriteria Penyisihan Penghapusan Aktiva Tetap (PPAP)}

Pengakuan penyisihan pendapatan aset berdasarkan metode langsung dan cadangan. Metode tersebut digunakan berdasarkan pada praktik umum bank, di mana akrual kerugian atas aset penerima sering terjadi pada periode setelah penempatan aset penerima, sedangkan laporan rugi/laba bank harus mencerminkan rasio berikut: pendapatan dan pengeluaran. Untuk alasan ini, bank menggunakan metode cadangan saat mencatat penyisihan penyimpanan aset.

Dengan metode cadangan ini, tidak harus sampai pada kerugian untuk diakui untuk mengakui kerugian pada aset penerima, tetapi bank harus membentuk cadangan untuk aset cadangan dan mengakuinya pada periode yang sama dengan pembagian aset. aset penerima manfaat. Cadangan ini dibentuk/ditambah dengan penyediaan aset penerima, dan diakui dan digunakan (dikurangi) jika aset penerima benar-benar hilang. Bank yang menghapuskan aset penerimanya harus menggunakan cadangan yang telah dibuat sebelumnya. Pada tanggal 31 Desember 2016, provisi aset penerima manfaat diakui dengan menyesuaikan pos-pos yang berlaku berdasarkan jenisnya.

Langkah selanjutnya memutuskan level PPAP mana yang akan dibuat. Dalam hal ini perlu dibuat PPAP seperti cadangan umum dan cadangan khusus terhadap kemungkinan kerugian. Cadangan ini dari aktiva produktif tersebut yaitu:

1. $1 \%$ Sekurang-kurangnya dari aktiva produktif yang digolongkan lancar, tidak termasuk SBI dan surat utang pemerintah.

\footnotetext{
${ }^{3}$ Irna Meutia Sari, Saparuddin Siregar, and Isnaini Harahap, 'Penilaian Kualitas Aktiva Produktif Dalam Perbankan', Seminar Nasional Teknologi Komputer \& Sains (SAINSTEK), 2020, 499-503.
} 
2. Ditetapkannya cadangan umum PPAP dari aktiva produktif yang digolongkan lancar, tidak termasuk SBI dan surat utang pemerintah sekurang-kurangnya sebesar $1 \%$.

3. Ditetapkannya PPAP cadangan khusus sekurang-kurangnya sebesar:

a. 5\% dari aktiva produktif yang digolongkan dalam perhatian khusus

b. $15 \%$ dari aktiva produktif yang digolongkan kurang lancar setelah dikurangi dengan nilai agunan

c. $50 \%$ dari aktiva produktif yang digolongkan diragukan setelah dikurangi nilai agunan

d. $100 \%$ dari aktiva produktif yang digolongkan macet setelah dikurangi nilai agunan ${ }^{4}$

\section{e. Kegiatan Rekstrukturisasi Kredit}

Restrukturisasi dapat melibatkan tindakan yang menambah dana bank dan/atau kesepakatan bahwa seluruh atau sebagian dari kewajiban bunga yang telah jatuh tempo akan menjadi pokok pinjaman baru dan/atau penyertaan perusahaan, yang mungkin memerlukan perubahan secara penuh atau jadwal dan/atau persyaratan pengembalian. Ini akan menjadi sebagian. Restrukturisasi kredit merupakan upaya bank untuk meningkatkan aktivitas perkreditan debitur yang kesulitan memenuhi utangnya.

Bank melakukan restrukturisasi kredit dengan alasan berikut:

1) Kreditur tidak melunasi hutangnya sesuai dengan kontrak yang ditentukan dalam perjanjian pinjaman dan/atau perjanjian terkait, debitur memiliki

\footnotetext{
${ }^{4}$ amanita novi, 'Bab $12-$ PPAP'

$<$ https://www.google.com/url?sa=t\&rct=j\&q=\&esrc=s\&source=web\&cd=\&cad=rja\&uact=8\&ved= 2ahUKEwjq-

PGs0Kj0AhW29nMBHUq9CTsQFnoECAIQAQ\&url=http\%3A\%2F\%2Fstaffnew.uny.ac.id\%2Fupload \%2F132318570\%2Fpendidikan\%2Fbab-12-ppap.pdf\&usg=AOvVaw3CjATBNtmdrMmG9nG4cK9u>.
} 
itikad baik dan kepercayaan yang tinggi kepada manajemen dan memiliki sikap positif terhadap tanggung jawab pembayrannya.

2) Dalam restrukturisasi, ketika kreditur tidak mampu membayar sesuai dengan kontrak, sehingga usaha kreditur dapat berlanjut dan hanya sebagian dari utang yang dapat dibayar, sehingga restrukturisasi terjadi dan debitur sehat dan masih bekerja dan bekerja terus menerus.

3) Memperkuat posisi bank dapat dilakukan dengan memperbaiki dokumentasi hukum.

4) Jika bank yakin bahwa kreditur akan membayaran pembayaran kewajbannya setelah melakukan restrukturisasi kredit.

5) Keyakinan bank akan adanya prospek yang membaik dari usaha kreditur.

6) Dana tidak dapat ditarik seluruhnya oleh bank melalui eksekusi jaminan kredit yang telah diberikan pada kreditur

Untuk memperbaiki aktivitas perkreditan kreditur yang kesulitan membayar utangnya bank berupaya melakukannya dengan rektrukturisasi kredit. Selain itu, restrukturisasi atau reorganisasi pinjaman memiliki arti yang berbeda, seperti mengubah kondisi pinjaman dengan menyuntikkan tambahan dana bank, mengubah sebagian/seluruh kewajiban bunga menjadi pokok baru, atau mengubah sebagian pokok pinjaman. / Semua pemberi pinjaman untuk partisipasi bank atau untuk menarik mitra lain untuk meningkatkan partisipasi. ${ }^{5}$

\section{f. Penerapan Prinsip Mengenal Nasabah}

Mengenal nasabah merupakan cara yang paling berhasil bagi bank untuk mengatasi tindak pidana pencucian uang dan aktivitas pasar modal yang mempengaruhi penilaian masyarakat, nasabah atau mitra perbankan dalam kaitannya dengan bank yang terlibat, yaitu risiko operasional. dan risiko reputasi.

\footnotetext{
${ }^{5}$ ZELVIRA NATASYA NURRAHM, 'ANALISIS YURIDIS TERHADAP PELAKSANAAN RESTRUKTURISASI KREDIT MACET SEBAGAI SOLUSI PERJANJIAN KREDIT DALAM SITUASI COVID 19', 2021.
} 
risiko reputasi) (NHT Siahaan, 2002: 74). (reputation risk) (N.H.T. Siahaan, 2002 : 74).

Risiko operasional lebih kepada risiko bahwa tidak hanya pedagang efek tetapi juga pedagang atau perantara efek dapat melakukan bisnis normal karena kesalahan, penyalahgunaan wewenang, ketidakpastian dana cadangan, kurangnya struktur kontrol (internal), kurangnya prosedur, dan pelanggaran manajemen. . sistem Informasi. Gangguan sistem pembayaran di bidang telekomunikasi dan perdagangan surat berharga. Banyak risiko operasional yang terkait dengan mengetahui nasabah terkait dengan program perantara, kelemahan program perantara dan perantara dan perdagangan sekuritas, prosedur pengawasan yang tidak efisien, dan ketidakpatuhan bank terhadap due deligence.

Kenyataan bahwa pialang atau broker dan perantara pedagang efek tidak memperhatikan kontrak atau aspek hukum dari kontrak, dan broker serta pedagang efek dapat dikenakan tindakan hukum sebagai hasil. Kami tidak mematuhi prinsip mengenal nasabah ini merupakan dasar timbulnya Risiko hukum.. ${ }^{6}$

\section{Analisis Capital Adequacy Ratio (CAR)}

CAR atau analisis capital adequacy adalah ukuran kecukupan modal yang menggambarkan seberapa mampu bank untuk memelihara kecukupan modal dan kemampuan memanajemen bank untuk di identifikasi, diukur, dikendalikan dan mengendalikan risiko yang dapat mempengaruhi permodalan bank. ${ }^{7}$

\footnotetext{
${ }^{6}$ Alis Yulia, 'Prinsip Mengenal Nasabah (Know Your Customer Principle) Oleh Penyedia Jasa Keuangan Di Bidang Pasar Modal’, Jurnal IImiah Galuh Justisi, 7.1 (2019), 29 


\section{$\mathrm{CAR}=$ Modal $/$ Aktiva tertimbang menurut risiko $\times 100 \%$}

\section{Financing To Deposit Ratio (FDR)}

(Rivai dan Arifin, 2010: 748) FDR atau Financing to Deposit Ratio merupakan perbandingan dana pihak ketiga dengan dana yang disediakan bank. Untuk mengukur seberapa efektif pendanaan yang diberikan bank syariah maka pengukuran dilakukan menggunakan FDR. Oleh karena itu (Widyaningrum, 2015) peningkatan FDR juga meningkatkan keuntungan bank, dengan asumsi mampu menghimpun dana secara efisien. Sumarlin, 2016) Tingakat profitabilitas bank syariah dapat dipengaruhi oleh FDR. Dalam surat edaran BI Nomor 26/5/BPPP tanggal 2 Mei 1993, FDR tidak boleh melebihi 110\% ini merupakan ketetapan BI. Semakin tinggi FDR, semakin banyak uang yang masuk ke dana pihak ketiga. Ketika dana pihak ketiga dialokasikan, pendapatan atau profitabilitas meningkat (Sumarlin, 2016).

Suatu bank akan terpengaruh profitabilitasnya tergantung pada besar kecilnya rasio FDR. Semakin banyak uang yang dibagikan kepada nasabah dalam bentuk pinjaman, semakin sedikit juga dana yang menganggur dan semakin banyak pendapatan yang Anda terima. Ini tentu saja meningkatkan FDR yang pastinya akan meningkatkan profitabilitas bank.Menurut Dendawijaya (2009:116), FDR merupakan perbandingan jumlah total pinjaman yang bank berikan dengan dana yang diterima bank. Rasio ini mencerminkan salah satu perkiraan likuiditas bank dan dapat dirumuskan sebagai berikut: ${ }^{8}$

FDR = Jumlah dana yg diberikan / Total DPK x 100\%

\footnotetext{
${ }^{8}$ Raturandang and others.
} 


\section{E. Non-Performance Financing (NPF)}

Secara pengertian NPF atau Non-Performing Financing merupakan risiko pendanaan/pembiayaan. Risiko tersebut timbul jika bank gagal memperoleh kembali kontribusi besar atau keuntungan yang diperoleh dari pembiayaan atau investasi yang diberikan (Arifin, 2009: 263).

Dalam perbankan syariah risiko ini disebut pendanaan yang buruk. Pembiayaan yang buruk/bermasalah ini terjadi karena bank melakukan pendanaan tetapi nasabanya tidak mampu membayar atau mengansur sesuai dengan akad yang disepakati sebelumnya oleh kedua belah pihak hal ini berpengaruh pada naik turunnya pendanaan dalam perbankan syariah.

NPF menunjukkan bahwa bank yang sehat apabila rasio maksimalnya sebesar 5\%. Rasio NPF dapat dihitung menggunakan rumus berikut ini:

Rasio NPF $=($ Total NPF/ Total Kredit $) \times 100 \%$

\section{F. Beban Operasional Terhadap Pendapatan Operasional (BOPO)}

Mengelola beban dan pendapatan operasional merupakan kemampuan bank dalam kinerja operasionalnya. Rasio BOPO atau biaya operasional terhadap pendapatan operasional digunakan dalam mengukur prestasi kerja sebuah bank. Biaya yang bank keluarkan untuk menjalankan usahanya ini disebut biaya operasional.

Berbeda dengan Dendawijaya (2009: 119) menurutnya perbandingan antara beban usaha dengan laba usaha, merupakan BOPO. Rendahnya rasio BOPO meningkat efisien biaya operasional yang bank keluarkan dan berkurangnya laba 
sebelum pajak juga meningkatnya laba operasional, yang nantinya menurunkan laba atau profit (ROA) dari bank itu sendiri. Berikut rumus Rasio BOPO9

\section{BOPO = Biaya Operasional $/$ Pendapatan Operasional x 100\%}

\section{G. Good Corporate Goverance}

Pada SE No. 15/15/DPNP Jakarta, 29 April 2013 (Bank Indonesia, 2013) Sehubungan dengan "Penerapan Good Corporate Governance (GCG) Bagi Bank Umum", seluruh bank umum umum di Indonesia menggunakan pendekatan berbasis risiko (RBBR) untuk melakukan penilaian sendiri (self-assessment) tingkat kehati-hatian bank. , Bank Indonesia in Commerce Dengan menggunakan pendekatan berbasis risiko (RBBR) terhadap kesehatan bank, penilaian kinerja GCG berdasarkan lima prinsip inti dikelompokkan ke dalam sistem manajemen yang terdiri dari tiga aspek manajemen: struktur manajemen, manajemen. proses dan hasil manajemen. ${ }^{10}$

\footnotetext{
${ }^{9}$ Muhammad Hilda Al Iqbal and Iwan Budiyanto, 'Analisis Pengaruh Kewajiban Penyediaan Modal Minimum (KPMM), Beban Operasional Pendapatan Operasional (BOPO), Financing To Deposit Ratio (FDR), Dan Inflasi Terhadap Return On Asset (ROA) Pada Bank Umum Syariah Di Indonesia Periode 2016-2019', MALIA: Journal of Islamic Banking and Finance, 4.1 (2020), 1 <https://doi.org/10.21043/malia.v4i1.6887>.

${ }^{10}$ Achmad Hasan Hafidzi, 'Penilaian Tingkat Kesehatan Perbankan Syariah Di Indonesia', Manajemen Dan Bisnis Indonesia, 6 (2020).
} 


\section{BAB IV}

\section{Kesimpulan}

Penilaian Kesehatan bank dapat dikatakan merupakan hasil penilaian tingkat kesehatan bank yang dilakukan untuk mengelola risiko dan kinerja bank, atau tingkat kesehatan bank dapat dikatakan mencerminkan kinerja tugas bank. Bank yang sehat adalah bank yang memelihara dan memelihara kepercayaan masyarakat, berperan sebagai perantara, berkontribusi terhadap kelancaran penyelesaian transaksi, dan tersedia bagi pemerintah untuk melaksanakan berbagai kebijakan, terutama kebijakan moneter.

Pemenuhan ketentuan UU Perbankan timbul dari kriteria penetapan rasio Penyedia Modal Minimum (RKPMM), Batas Maksimum Kredit (PBMK), kualitas aset pendapatan, dan pengecualian penyesuaian nilai untuk aset tetap. (PPAP), langkah restrukturisasi kredit dan penerapan prinsip, untuk mengenal nasabah. Juga analisis CAR, FDR, NPF, BOPO, GGC. 


\section{DAFTAR PUSTAKA}

amanita

$$
\text { novi, }
$$

'Bab

12

PPAP'

$<$ https://www.google.com/url?sa $=$ t\&rct $=\mathrm{j} \& \mathrm{q}=\&$ esrc $=$ s\&source $=$ web\&c $\mathrm{d}=\& \mathrm{cad}=$ rja\&uact $=8 \&$ ved $=2$ ahUKEwjq-

PGs0Kj0AhW29nMBHUq9CTsQFnoECAIQAQ\&url=http\%3A\%2F\% 2Fstaffnew.uny.ac.id\%2Fupload\%2F132318570\%2Fpendidikan $\% 2 F b a$ b-12-ppap.pdf\&usg=AOvVaw3CjATBNtmdrMmG9nG4cK9u>

Ginting, Ramlan, and Dkk, Kodifikasi Peraturan Bank Indonesia ASET, 2013

Hafidzi, Achmad Hasan, 'Penilaian Tingkat Kesehatan Perbankan Syariah Di Indonesia', Manajemen Dan Bisnis Indonesia, 6 (2020)

Iqbal, Muhammad Hilda Al, and Iwan Budiyanto, 'Analisis Pengaruh Kewajiban Penyediaan Modal Minimum (KPMM), Beban Operasional Pendapatan Operasional (BOPO), Financing To Deposit Ratio (FDR), Dan Inflasi Terhadap Return On Asset (ROA) Pada Bank Umum Syariah Di Indonesia Periode 2016-2019', MALIA: Journal of Islamic $\begin{array}{llll}\text { Banking } \quad \text { and } \quad \text { Finance, } & 4.1 & \text { (2020), } & 1\end{array}$ $<$ https://doi.org/10.21043/malia.v4i1.6887>

Kuswahariani, Wulandari, Hermanto Siregar, and Ferry Syarifuddin, 
'Analisis Non Performing Financing (Npf) Secara Umum Dan Segmen Mikro Pada Tiga Bank Syariah Nasional Di Indonesia', Jurnal Aplikasi Bisnis Dan Manajemen, $6.1 \quad$ (2020), 26-36 $<$ https://doi.org/10.17358/jabm.6.1.26>

NURRAHM, ZELVIRA NATASYA, ‘ANALISIS YURIDIS TERHADAP PELAKSANAAN RESTRUKTURISASI KREDIT MACET SEBAGAI SOLUSI PERJANJIAN KREDIT DALAM SITUASI COVID 19’, 2021

Raturandang, Ireyne Filania, Joula Rogahang, Dantje Keles, and Jurusan, 'Surat Edaran Bank Indonesia No:6/23/DPNP Tanggal 31 Mei 2004', Journal of Chemical Information and Modeling, 53.9 (2013), 1689-99

Sari, Irna Meutia, Saparuddin Siregar, and Isnaini Harahap, 'Penilaian Kualitas Aktiva Produktif Dalam Perbankan', Seminar Nasional Teknologi Komputer \& Sains (SAINSTEK), 2020, 499-503

Yulia, Alis, 'Prinsip Mengenal Nasabah (Know Your Customer Principle) Oleh Penyedia Jasa Keuangan Di Bidang Pasar Modal', Jurnal Ilmiah Galuh Justisi, 7.1 (2019), 29 <https://doi.org/10.25157/jigj.v7i1.2141> 